\title{
ANALISIS KINERJA DAN POTENSI PERTUMBUHAN RETURN PORTOFOLIO REKSADANA SAHAM DAN REKSADANA CAMPURAN
}

\author{
Ferikawita M. Sembiring dan Titianingsih Madjan*
}

Universitas Jend. A. Yani

\begin{abstract}
The purposes of this study are to analyze the performance of the stock mutual funds and composite mutual funds in Indonesia and to analyze the potency of the return growth of those mutual funds. This study used the monthly return (net asset valueNAV) of 7 stock mutual funds and 11 composite mutual funds, from January 2002 to December 2006*. The monthly composite index of the JSX is used as the proxy for market return. Jensen model is used as the tool to measure of the performance (indicated by Jensen alpha) and the potency of the return growth (indicated by beta). To get an accuracy of the analysis and to avoid bias beta problem, this beta has to be corrected with Fowler and Rorke model, adopted from Capital Asset Pricing Model (CAPM). The main results of this research explained that the performance and the potency of the return growth of the stock mutual funds are higher than the composite mutual funds, during the period of analysis.
\end{abstract}

Keywords: mutual funds, Jensen alpha, beta, biased beta

\section{Pendahuluan}

Didukung oleh pencanangan tahun 1996 sebagai Tahun Reksadana, perkembangan reksadana terbuka sebagai suatu sarana dan alternatif berinvestasi meningkat secara pesat dan telah menarik perhatian berbagai kalangan investor. Tempo (2006) mencatat bahwa sepanjang tahun 2006, pertumbuhan reksadana pasar vang secara signifikan telah mencapai $75,1 \%$, reksadana saham $53,3 \%$, reksadana campuran $46,3 \%$, dan reksadana pendapatan tetap $4,1 \%$. Berdasarkan data pertumbuhan tersebut, dapat diketahui bahwa posisi reksadana saham dan reksadana campuran (dengan unsur saham didalamnya) melebihi posisi reksadana pendapatan tetap. Hal ini mengindikasikan bahwa orientasi investasi investor yang semula cenderung sangat toleran terhadap risiko kini mulai berani dalam mempertimbangkan dan menghadapi risiko investasi tersebut karena mereka telah menyadari bahwa dalam jangka panjang, investasi pada saham merupakan jenis investasi yang sangat menjanjikan. Seperti yang dikemukakan oleh Utomo dan Nugraha (2002) bahwa "Investasi saham merupakan investasi pada perusahaanperusahaan yang dalam jangka panjang akan memberikan hasil investasi yang lebih besar daripada deposito maupun obligasi. Risiko yang terjadi karena hargaharga saham yang selalu berfluktuasi, lebih bersifat jangka pendek." 
Investasi pada saham pada awalnya memang dipersepsikan oleh beberapa investor sebagai suatu investasi jangka panjang yang lebih bersifat spekulatif. Terbatasnya kemampuan untuk menganalisis dan memilih saham, terbatasnya dana untuk melakukan diversifikasi, dan terbatasnya waktu untuk selalu memonitor kondisi pasar merupakan kendala utama yang umumnya dihadapi oleh para investor untuk berinvestasi pada saham secara langsung. Oleh karena itu, kehadiran instrumen reksadana (khususnya reksadana saham dan campuran) yang dikelola oleh manajer investasi diharapkan dapat membantu para investor dalam menghadapi keterbatasan tersebut.

Dari sudut pandang investor, masalah yang sebenarnya dihadapi adalah bagaimana memilih suatu reksadana dari berbagai alternatif reksadana yang ada. Dasar pemilihan biasanya ditinjau dari kinerja manajer investasi yang merefleksikan kinerja portofolio. Menurut Utomo dan Nugraha (2002 : 181), petunjuk yang paling kasat mata dalam memilih manajer investasi yang ahli adalah melalui kinerja historis beserta profil risk and return-nya. Pengukuran kinerja dengan melibatkan faktor risiko memberikan informasi yang lebih mendalam bagi investor tentang sejauh mana suatu hasil atau kinerja yang diberikan oleh manajer investasi dikaitkan dengan risiko yang diambil untuk mencapai kinerja tersebut.

Sembiring (2005) memberikan peringkat untuk delapan reksadana saham yang dinilai kinerjanya selama 36 bulan (periode tahun 2001-2003) dengan menggunakan model pengukuran kinerja Jensen. Indikator pemeringkatan adalah Jensen alpha yang merefleksikan kinerja portofolio reksadana dibandingkan dengan kinerja portofolio pasar (proxy: IHSG). Hasil analisis tersebut adalah sebagai berikut :

Tabel 1

Peringkat Reksadana Saham Peride 1 Januari 2001-31 Desember 2003

\begin{tabular}{clc}
\hline No & \multicolumn{1}{c}{ Reksadana Saham } & $\begin{array}{c}\text { Kinerja } \\
(\text { Jensen } \alpha)\end{array}$ \\
\hline 1 & Schroder Dana Prestasi Plus & 0.01530 \\
2 & Rencana Cerdas & 0.00964 \\
3 & Panin Dana Maksima & 0.00711 \\
4 & Phinisi Dana Saham & 0.00606 \\
5 & Bahana Dana Prima & 0.00438 \\
6 & ABN Amro ID Saham & 0.00225 \\
7 & BNI Dana Berkembang & 0.00077 \\
8 & Big Nusantara & -0.00099 \\
\hline
\end{tabular}

Sumber : Ferikawita M. Sembiring, 2005

Jensen alpha $(\alpha)$ mengindikasikan bagaimana kinerja portofolio reksadana dibandingkan dengan kinerja portofolio pasar. Schroeder misalnya, nilai alpha sebesar 0.01530 menunjukkan bahwa kinerja reksadana Schroder selama periode 1 
Januari 2001 - 31 Desember 2003 adalah sebesar 1.530\% lebih tinggi daripada kinerja portofolio pasar.

Dari model Jensen juga dapat diketahui nilai beta yang merupakan indikator risiko pasar sekaligus sebagai indikator potensi pertumbuhan return reksadana. Dengan mempertimbangkan kondisi pasar modal Indonesia yang tidak efisien (un-efficiency market), maka untuk mengurangi kemungkinan bias pada interpretasi nilai beta tersebut harus dilakukan koreksi bias beta dengan menggunakan model Fowler dan Rorke. Estimasi beta yang tidak bias dapat lebih akurat dalam menginterpretasikan potensi pertumbuhan return portofolio reksadana.

Dari hasil penelitiannya, Sembiring (2005) menyajikan informasi potensi pertumbuhan return reksadana saham yang dapat dilihat pada tabel berikut :

Tabel 2

Potensi Pertumbuhan Return Portofolio Reksadana Saham Periode 1 Januari 2001 - 31 Desember 2003

\begin{tabular}{clc}
\hline No & \multicolumn{1}{c}{ Reksadana } & Beta $(\beta)$ \\
\hline 1 & Schroder Dana Prestasi Plus & 0.969 \\
2 & Panin Dana Maksima & 0.937 \\
3 & Bahana Dana Prima & 0.989 \\
4 & Phinisi Dana Saham & 1.049 \\
5 & ABN Amro ID Saham & 0.927 \\
6 & Rencana Cerdas & 0.968 \\
7 & Big Nusantara & 0.745 \\
8 & BNI Dana Berkembang & 0.889 \\
\hline
\end{tabular}

Sumber : Ferikawita M. Sembiring, 2005

Telah disebutkan bahwa koefisien beta merupakan indikator risiko pasar sekaligus menunjukkan potensi pertumbuhan return portofolio reksadana. Schroeder misalnya, beta sebesar 0.969 menunjukkan berarti bahwa potensi pertumbuhan return reksadana Schroder selama periode 1 Januari 2001 - 31 Desember 2003 adalah sebesar 0.031 atau $3.1 \%$ di bawah pertumbuhan return pasar.

Untuk penelitian ini, peneliti akan meneliti kembali kinerja dan potensi pertumbuhan return portofolio reksadana saham dengan mengambil periode penelitian yang lebih panjang, yaitu 60 bulan (5 tahun), terhitung 1 Januari 2002 sampai dengan 31 Desember 2006. Selain itu, peneliti juga akan mencoba membandingkan kinerja dan potensi pertumbuhan return portofolio reksadana saham ini dengan reksadana campuran yang memasukkan sekuritas saham sebagai salah satu unsur investasinya.

Berdasarkan uraian yang telah disajikan dalam latar belakang, maka permasalahan yang dirumuskan dalam penelitian ini adalah sebagai berikut : 
1. Bagaimana kinerja portofolio reksadana saham dan reksadana campuran selama tahun 2002 sampai dengan tahun 2006, berdasarkan data bulanan.

2. Bagaimana potensi pertumbuhan return portofolio reksadana saham dan reksadana campuran selama tahun 2002 sampai dengan tahun 2006, berdasarkan data bulanan.

3. Bagaimana kinerja dan potensi pertumbuhan return portofolio reksadana saham dibandingkan dengan reksadana campuran selama tahun 2002 sampai dengan tahun 2006, berdasarkan data bulanan.

Manfaat yang diharapkan dari penelitian ini adalah :

1. Manfaat teoritis

Hasil penelitian ini diharapkan dapat bermanfaat bagi pengembangan ilmu dalam bidang manajemen keuangan, khususnya tentang kinerja portofolio reksadana saham dan reksadana campuran serta potensi pertumbuhan returnnya.

2. Manfaat praktis

Hasil penelitian ini diharapkan dapat bermanfaat dalam menyelesaikan permasalahan yang dihadapi oleh pihak-pihak yang terkait, khususnya bagi investor yang hendak berinvestasi pada portofolio reksadana saham dan reksadana campuran.

\section{Landasan Teori dan Pengembangan Hipotesis}

Investasi yang dilakukan oleh masyarakat pada dasarnya bertujuan untuk memenuhi kebutuhan pada masa yang akan datang dengan cara menempatkan sebagian pendapatan yang diperoleh saat ini pada berbagai instrumen investasi yang menjanjikan nilai lebih pada masa mendatang. Oleh karena berhubungan dengan masa yang akan datang, maka faktor risiko harus dipertimbangkan karena faktor ini akan berpengaruh terhadap nilai investasi. Dalam situasi ketidakpastian, investor tidak dapat mengetahui secara pasti tingkat keuntungan yang akan diperoleh, oleh karena itu, untuk mengurangi tingkat risiko yang akan ditanggung, para investor melakukan diversifikasi investasi. Penerapan prinsip diversifikasi bukan hanya mengurangi risiko kerugian, namun dalam jangka panjang dapat mengoptimumkan tingkat hasil yang ingin dicapai. Upaya melakukan diversifikasi investasi pada berbagai instrumen investasi ini dikenal dengan istilah manajemen portofolio. Menurut Jones (2000: 12) :

"Portfolio management involves a series of decisions and actions that must be made by every investors, whether individual or institution. Portfolio management can be thought of as a process. Having structured portfolio 
management as a process, any portfolio manager can execute the necessary decisions for an investor. The process provides a framework and a control over the diverse activities involved, and allows every investors, individual or institution, to be accommodated in a systematic, orderly manner."

Senada dengan pendapat Jones di atas, Utomo dan Nugraha (2002 : 32) menyatakan bahwa manajemen portofolio investasi merupakan suatu proses yang sistematis, dinamis, dan kontinyu (berkelanjutan). Manajemen portofolio investasi (dengan manajer investasi sebagai pelaku manajemen) akan memberikan suatu kerangka kerja (framework) bagi pengelolaan investasi yang mencakup proses perencanaan, implementasi, evaluasi dan penyesuaian. Dengan mengikuti kerangka kerja tersebut, maka pengelolaan investasi dapat memberikan hasil yang optimal.

Perusahaan investasi (investment companies) merupakan perusahaan yang menyediakan jasa keuangan dengan cara menjual sahamnya ke publik dan menggunakan dana yang diperoleh tersebut untuk diinvestasikan ke dalam portofolionya. Perusahaan investasi dapat diklasifikasikan sebagai unit investment trust, closed-end investment companies dan open-end investment companies (Jogiyanto, $1998:$ 9-10).

Open-end investment companies disebut juga sebagai perusahaan reksadana (mutual fund). UU Pasar Modal No. 8 tahun 1995 pasal 1 ayat 27 menyebutkan bahwa reksadana adalah "...... wadah yang dipergunakan untuk menghimpun dana dari masyarakat pemodal untuk selanjutnya diinvestasikan dalam portofolio efek oleh manajer investasi yang telah mendapat izin dari Bapepam."

BAPEPAM (1997 : 9-10) membedakan jenis-jenis reksadana berdasarkan konsentrasi dalam portofolio efeknya, meliputi reksadana pasar vang, reksadana pendapatan tetap, reksadana saham, dan reksadana campuran. Reksadana pasar uang merupakan reksadana yang hanya melakukan investasi pada efek bersifat utang dengan jatuh tempo kurang dari 1 (satu) tahun, reksadana pendapatan tetap melakukan investasi sekurang-kurangnya $80 \%$ dari aktivanya dalam bentuk efek bersifat utang, reksadana saham melakukan investasi sekurang-kurangnya $80 \%$ dari aktivanya dalam bentuk efek bersifat ekuitas, dan reksadana campuran melakukan investasi dalam efek bersifat ekuitas dan bersifat utang yang perbandingannya tidak termasuk reksadana pendapatan tetap dan reksadana saham.

Dibandingkan dengan reksadana pasar uang dan reksadana pendapatan tetap, reksadana saham dan reksadana campuran (dengan asumsi saham merupakan aset terbesar di dalam komposisi investasinya), memberikan potensi pertumbuhan nilai investasi yang lebih besar namun diimbangi juga dengan tingkat risiko yang lebih tinggi. Oleh karena itu, investor membutuhkan manajer investasi yang sangat ahli dalam bidang pengelolaan dana. 
Sebagian besar penelitian sebelumnya memang menyatakan bahwa kinerja portofolio reksadana terbukti tidak lebih baik daripada kinerja portofolio pasar (underperform the market), hal ini didasarkan pada penelitian Jensen di USA (dalam Chuan, 1995 : 23 ; Mohamed dan Nassir, 1995 : 54 ; Denis, Manurung dan Nachrowi, 2004 : 225), Chuan di Malaysia (1995), serta Ariff dan Johnson di Singapura (dalam Mohamed dan Nassir, 1995 : 54). Namun Sembiring (2005) menyebutkan bahwa pasca booming tahun 2000, reksadana saham di Indonesia memiliki kinerja superior.

Sembiring (2005) menyatakan bahwa peluang kinerja reksadana akan mampu mengungguli kinerja pasarnya, didasari oleh hal-hal berikut ini : (1) Kinerja portofolio pasar (proxy : IHSG) diukur berdasarkan return dari seluruh aset (saham) di bursa, baik saham yang likuid maupun yang tidak likuid, sedangkan pada portofolio reksadana saham, kinerjanya diukur berdasarkan return dari komposisi portofolio saham yang pada umumnya merupakan jenis saham yang likuid, seperti sahamsaham LQ 45, (2) Adanya kebijakan investasi bagi reksadana saham untuk dapat berinvestasi pada efek selain saham, seperti obligasi dan deposito (maksimal 20\% dari dana kelolaan) yang memberikan tingkat return yang relatif stabil, (3) Selain menerapkan strategi pasif, manajer investasi juga menerapkan strategi aktif dimana para manajer investasi akan secara aktif selalu mengevaluasi nilai aset (saham) yang berubah nilai intrinsiknya akibat perubahan pasar, (4) Semakin maraknya aktivitas investasi pada instrumen reksadana saham pasca booming reksadana tahun 2000, hal ini mendukung pendapat Utomo dan Nugroho (2002 : 73) yang menyebutkan bahwa pada periode-periode pasca booming reksadana tahun 2000, tetap ada peluang bahwa kinerja reksadana dapat mengungguli kinerja pasarnya, khususnya dalam periode estimasi yang lebih panjang.

Selanjutnya dalam kaitannya dengan tingkat risiko, Jogiyanto (1998) menyatakan bahwa risiko yang relevan untuk dipertimbangkan dalam portofolio adalah risiko sistematik atau disebut juga sebagai risiko pasar (market risk). Risiko sistematik terkait dengan faktor-faktor ekonomi makro yang dapat mempengaruhi semua sekuritas yang ada sehingga menyebabkan semua saham cenderung untuk "bergerak bersama". Oleh karena selalu ada dalam setiap saham, maka risiko sistematik ini tidak dapat dihilangkan melalui pembentukan portofolio.

Pengukur risiko sistematik dari suatu sekuritas atau portofolio relatif terhadap risiko pasar adalah beta (Jones, 2000 ; Elton dan Gruber, 2003). Beta ( $\beta$ ) menggambarkan sensitivitas perubahan kinerja portofolio dibandingkan dengan kinerja pasar, atau dengan kata lain bahwa beta adalah suatu ukuran untuk melihat fluktuasi kinerja sebuah portofolio dibandingkan dengan tolok ukurnya. Suatu portofolio reksadana dengan beta sama dengan satu $(\beta=1)$, artinya mempunyai tingkat risiko yang sama dengan tolok ukurnya. Reksadana dengan beta kurang dari satu $(\beta<1)$, artinya mempunyai risiko yang lebih kecil daripada risiko tolok ukurnya sehingga potensi pertumbuhannya juga lebih kecil, sedangkan reksadana dengan beta lebih dari satu $(\beta>1)$, potensi pertumbuhannya lebih besar daripada tolok ukurnya. Dengan demikian reksadana dengan beta lebih dari satu, misalnya, 1,1, 
diperkirakan return-nya akan berfluktuasi antara 10 persen di bawah dan 10 persen di atas tolok ukur, atau dengan kata lain, return tersebut akan lebih tinggi 10 persen bila pasar sedang membaik, atau akan turun sebesar 10 persen bila pasar sedang memburuk. Semakin tinggi ukuran nilai beta, maka semakin tinggi pula risiko investasi.

Cahyono (2002) menyatakan bahwa banyak reksadana saham di Indonesia mempunyai beta di bawah satu, artinya tingkat risiko portofolionya lebih rendah daripada risiko pasar. Hal ini terjadi karena belum semua aset reksadana saham diinvestasikan ke dalam efek saham sehingga fluktuasi return reksadana tersebut lebih rendah dibandingkan dengan fluktuasi return tolok ukur-nya, yaitu portofolio pasar.

Sembiring (2005) juga menyebutkan bahwa secara umum, potensi pertumbuhan return portofolio reksadana saham cenderung lebih kecil daripada return portofolio pasar. Hal ini diindikasikan oleh nilai beta portofolio yang lebih rendah daripada 1. Koefisien determinasi $\left(R^{2}\right)$ yang merupakan indikator diversifikasi risiko secara keseluruhan juga bernilai kurang dari 1, ini berarti bahwa diversifikasi yang dilakukan belum mencapai diversifikasi sempurna (perfectly diversified).

Adanya fenomena pasar yang tipis (thin market) akibat perdagangan saham yang jarang terjadi, banyak ditemukan pada pasar modal yang sedang berkembang sehingga sering muncul masalah non-synchronous trading (perdagangan yang tidak sinkron) yang dapat menimbulkan bias dalam pengestimasian beta. Fenomena ini juga terjadi pada pasar modal Indonesia, yaitu di Bursa Efek Jakarta (Hartono, 1998 ; Suwandi, 1997, dalam Lantara, 2000 : 18). Suwandi menyatakan bahwa pasar modal Indonesia merupakan pasar modal yang tipis, ditandai oleh tiga karakteristik utama, yaitu : (1) Tingkat likuiditas yang rendah, (2) Kapitalisasi pasar yang tidak merata, dan (3) Rendahnya tingkat kepemilikan saham yang dilepas ke publik. Farrel (1974, dalam Lantara, 2000 : 19) berpendapat bahwa estimasi beta dalam pasar yang tergolong sebagai pasar tipis (thin market) akan menimbulkan kesalahan pengukuran (measurement error). Penyebabnya adalah karena indeks pasar yang dipakai untuk menghitung beta saham-saham individual pada dasarnya hanya merupakan rata-rata dari sekitar 25\% dari total saham yang ada di pasar. Sebagai konsekuensinya, mungkin akan terjadi estimasi yang terlalu tinggi (over estimation) terhadap beta saham-saham yang relatif sering diperdagangkan (frequently trading stocks), atau akan terjadi estimasi yang terlalu rendah (under estimation) terhadap beta saham-saham yang tergolong jarang diperdagangkan (infrequently trading stocks).

Kondisi perdagangan yang jarang terjadi selanjutnya akan memunculkan permasalahan non-synchronous trading dalam pengestimasian beta. Menurut Ariff dan Johnson (1990), permasalahan non-synchronous trading terjadi ketika indeks pasar pada waktu $t$, disusun dari harga penutupan (closing price) saham yang tidak 
sinkron pada saat $t$ tersebut. Semakin besar tingkat ketipisan suatu pasar (degree of thinly market), semakin besar tingkat bias beta saham.

Berdasarkan kondisi tersebut, Hartono dan Surianto (1999) menyatakan bahwa beta pada pasar modal yang sedang berkembang seperti di Indonesia perlu disesuaikan karena beta tersebut masih merupakan beta yang bias. Beta yang bias dapat mengurangi keakuratan hasil estimasi return yang diharapkan dari suatu investasi. Oleh karena itu, untuk meningkatkan keakuratan estimasi return suatu investasi, investor memerlukan estimasi ukuran risiko sistematis yang tidak bias. Hal ini mendorong dikembangkannya berbagai metode untuk mengurangi bias beta yang terjadi, antara lain metode yang dikemukakan oleh Scholes dan Williams (1977), Dimson (1979), serta Fowler dan Rorke (1983).

Berdasarkan data bulanan, Ariff dan Johnson (1990, dalam Jogiyanto, 1998 : 246) menggunakan ketiga metode tersebut untuk mengoreksi bias beta di Pasar Modal Singapura. Hasil penelitian menunjukan bahwa metode yang paling tepat untuk mengoreksi bias beta di bursa Singapura adalah metode koreksi Fowler dan Rorke. Demikian juga dengan Nassir dan Shamser (1996) yang menggunakan metode yang sama di Pasar Modal Malaysia, Hartono dan Surianto (1999) serta Tandelilin dan Lantara (2001) di Bursa Efek Jakarta (BEJ) Indonesia.

Adapun alasan lain yang sering dikemukakan sebagai penyebab munculnya masalah bias beta adalah karena adanya estimasi beta yang bias akibat penggunaan metode estimasi OLS terhadap saham-saham yang dipengaruhi oleh thin trading. Masalah nonstationary beta yang menyebabkan estimasi beta menjadi bias tersebut, dalam penelitian ini akan dikoreksi melalui metode koreksi Fowler dan Rorke yang secara empirik lebih tepat diterapkan di Pasar Modal Indonesia. Namun menurut Jogiyanto (1998 : 244), penggunaan periode lead dan lag yang terlalu banyak pada metode Fowler dan Rorke, justru akan meningkatkan bias yang terjadi. Oleh karena itu, perlu dilakukan pengujian pada periode lead dan lag berapa bias beta portofolio akan terkoreksi.

Selanjutnya dalam kaitannya dengan portofolio reksadana, oleh karena kinerja reksadana sangat ditentukan oleh kepiawaian manajer investasi dalam mengelola dana investasi, maka investor reksadana akan sangat bergantung pada kemampuan manajer investasi dalam memilih sekuritas yang tepat (security selection ability) dan pada saat yang tepat (timing ability). (Reily dan Brown, 2003 : $1116)$

Jika manajer investasi cenderung lebih memilih saham-saham dengan beta relatif rendah maka tingkat return portofolio juga akan relatif rendah sehingga kinerja yang mereka peroleh, secara rata-rata, tidak lebih baik daripada kinerja portofolio pasar. Saham-saham dengan beta yang rendah ditunjukkan oleh harganya yang tinggi di bursa. Yuliati, Prasetyo dan Tjiptono (1996: 108) menyatakan bahwa terdapat hubungan yang tidak searah (negatif) antara beta dan harga saham (cateris paribus). Saham-saham dengan harga yang tinggi mengisyaratkan tingkat 
return yang lebih rendah karena risiko sistematik yang dihadapi juga lebih kecil. Sebaliknya, saham-saham dengan harga rendah, mengisyaratkan tingkat return yang lebih tinggi karena risiko sistematik yang dihadapi juga lebih besar.

Harga suatu aset akan ditentukan oleh risiko sistematik yang dicerminkan oleh beta aset tersebut. Semakin besar nilai beta, maka investor akan menetapkan tingkat keuntungan yang semakin besar pula. Apabila asumsi cateris paribus dipegang, dengan semakin tinggi required rate of return, maka harga aset akan semakin rendah. Harga aset pada hakekatnya merupakan nilai sekarang dari aliran kas masuk bersih aset tersebut ditambah harga aset pada periode tertentu (di masa yang akan datang). Tingkat keuntungan yang diharapkan akan digunakan sebagai faktor diskonto. Apabila tingkat keuntungan tersebut semakin besar, maka harga aset akan semakin murah (cateris paribus). Tingkat keuntungan yang diharapkan dari suatu aset merupakan fungsi dari beta aset tersebut. Secara tidak langsung, harga aset akan ditentukan oleh beta (risiko sistematik) aset. Dengan demikian, harga aset akan memiliki hubungan yang negatif dengan nilai betanya (cateris paribus).

Adapun untuk reksadana saham di Indonesia, pada umumnya saham-saham dalam portofolio-nya merupakan jenis saham yang likuid, seperti saham-saham LQ 45. Saham-saham likuid merupakan saham-saham dengan trading rate yang relatif tinggi dan mendominasi volume perdagangan di bursa. Trading-rate yang tinggi ditunjukkan oleh demand yang tinggi atas saham tersebut sehingga harganya pun akan tinggi pula, namun hal ini mengindikasikan relatif rendah-nya tingkat return portofolio reksadana saham karena risiko sistematik yang dihadapi juga relatif rendah.

Dengan demikian, berdasarkan seluruh uraian yang telah disajikan dalam kerangka pemikiran, maka berikut ini akan dirumuskan suatu hipotesis penelitian. Sebelum dirumuskan, beberapa hal yang menjadi pertimbangan adalah sebagai berikut:

- Berdasarkan hasil penelitiannya, Sembiring (2005) menyatakan bahwa kinerja reksadana (saham) memiliki kinerja superior terhadap kinerja portofolio pasar (outperform the market). Dalam penelitian ini akan diuji kembali apakah kinerja tersebut tetap berlaku dalam periode penelitian yang lebih panjang atau justru sebaliknya.

- Dalam penelitian ini juga akan dianalisis kinerja portofolio reksadana campuran dengan asumsi bahwa saham merupakan jenis sekuritas dengan proporsi terbesar dalam portofolio

- Pada reksadana campuran, selain saham, portofolio-nya juga dibentuk dari berbagai jenis sekuritas, seperti obligasi atau deposito yang memiliki tingkat return yang relatif tetap dengan tingkat risiko yang lebih rendah daripada saham 
Berdasarkan hal-hal tersebut, maka hipotesis penelitian ini adalah :

a. Kinerja portofolio reksadana campuran lebih tinggi dibandingkan dengan kinerja portofolio reksadana saham

b. Beta portofolio reksadana campuran lebih rendah daripada beta portofolio reksadana saham. Hal ini berarti bahwa potensi pertumbuhan return portofolio reksadana campuran lebih rendah dibandingkan potensi pertumbuhan return portofolio reksadana saham.

\section{Metode Penelitian}

Variabel penelitian yang akan dioperasionalisasikan ditunjukkan dalam tabel berikut:

Tabel 3

Operasionalisasi Variabel

\begin{tabular}{|c|c|c|c|c|}
\hline Variabel & Konsep Variabel & Indikator & Satuan & $\begin{array}{l}\text { Skala } \\
\text { Ukur }\end{array}$ \\
\hline $\begin{array}{l}\text { Variabel Bebas } \\
\text { Kelebihan } \\
\text { pengembalian } \\
\text { (excess return) } \\
\text { portofolio } \\
\text { pasar }\end{array}$ & $\begin{array}{l}\text { Selisih dari return } \\
\text { portofolio pasar } \\
\text { dengan return } \\
\text { investasi bebas } \\
\text { risiko }\end{array}$ & $\begin{array}{l}\text { Selisih dari tingkat return Indeks } \\
\text { Harga Saham Gabungan (IHSG) } \\
\text { dan tingkat return suku bunga } \\
\text { Sertifikat Bank Indonesia (SBI) } \\
\text { selama sub periode } \\
\text { pengamatan, atau : ( } \mathbf{R}_{\mathbf{M t}}-\mathbf{R}_{\mathrm{RFt}} \text { ) }\end{array}$ & Persen & Rasio \\
\hline $\begin{array}{l}\text { Variabel } \\
\text { Terikat } \\
\text { Kelebihan } \\
\text { pengembalian } \\
\text { (excess return) } \\
\text { portofolio } \\
\text { reksadana }\end{array}$ & $\begin{array}{l}\text { Selisih dari return } \\
\text { portofolio } \\
\text { reksadana } \\
\text { dengan return } \\
\text { investasi bebas } \\
\text { risiko }\end{array}$ & $\begin{array}{l}\text { Selisih dari tingkat return } \\
\text { portofolio reksadana dan tingkat } \\
\text { return suku bunga Sertifikat Bank } \\
\text { Indonesia (SBI) selama sub } \\
\text { periode pengamatan, atau : ( } \mathbf{R}_{\mathbf{P t}} \\
\text { - } \mathbf{R}_{\mathbf{R F t}}\end{array}$ & Persen & Rasio \\
\hline
\end{tabular}

Dari hasil regresi kedua variabel di atas akan diperoleh nilai $\alpha$ dan $\beta$. Nilai $\alpha$ menunjukkan kinerja portofolio reksadana dan nilai $\beta$ menunjukkan risiko sistematik atau risiko pasar yang merupakan indikator potensi pertumbuhan return portofolio reksadana. Dalam penelitian ini terdapat dua populasi, yaitu populasi reksadana saham yang tetap aktif beroperasi sepanjang tahun 2002 sampai dengan tahun 2006, dan populasi reksadana campuran yang tetap aktif beroperasi sepanjang tahun 2002 sampai dengan tahun 2006, meliputi : 
Tabel 4

Reksadana Saham dan Campuran Aktif Selama Tahun 2002 - 2006

\begin{tabular}{|c|c|c|}
\hline \multirow{2}{*}{ No } & \multicolumn{2}{|c|}{ Populasi } \\
\hline & Reksadana Saham & Reksadana Campuran \\
\hline 1 & Bahana Dana Prima & Anggrek \\
\hline 2 & Big Nusantara & Bahana Dana Infrastruktur \\
\hline 3 & BNI Dana Berkembang & Bahana Dana Selaras \\
\hline 4 & Panin Dana Maksima & Mahanusa Dana Kapital \\
\hline 5 & Phinisi Dana Saham & Master Berimbang (BILLIS) \\
\hline 6 & Rencana Cerdas & PNM Syariah \\
\hline 7 & Schroder Dana Prestasi Plus & Sam Dana Berkembang \\
\hline 8 & & Schroder Dana Prestasi \\
\hline 9 & & Schroder Dana Terpadu \\
\hline 10 & & Simas Satu \\
\hline 11 & & Syariah Berimbang \\
\hline
\end{tabular}

Adapun sampel dalam penelitian ini adalah ukuran waktu yang digunakan untuk menilai kinerja dan potensi pertumbuhan return reksadana saham dan campuran. Berdasarkan hal tersebut maka data yang dipergunakan merupakan kombinasi antara data runtut waktu (time series) dan data silang tempat (cross section), atau disebut juga sebagai data pooling (pooled data). (Kuncoro, 2001 : 25). Data-data penelitian merupakan data sekunder dan diperoleh dari BAPEPAM, Pusat Referensi Pasar Modal BEJ dan Bank Indonesia (BI).

Metode analisis yang digunakan adalah metode analisis kuantitatif, sebagai berikut:

1. Untuk mengukur derajat diversifikasi portofolio reksadana digunakan alat ukur koefisien determinasi atau R². (Chuan, 1995 ; Mohamed dan Nassir, 1995 ; Jones, 2000). Semakin terdiversifikasi suatu portofolio maka nilai $R^{2}$ akan semakin mendekati 1,0. Nilai $R^{2}$ sebesar 1,0 menunjukkan bahwa return portofolio tersebut sepenuhnya dapat dijelaskan oleh return pasar.

2. Untuk mengukur kinerja portofolio reksadana, digunakan Jensen Portfolio Performance Measure (Jensen alpha) dengan model sebagai berikut :

$$
\left(R_{P t}-R_{R F t}\right)=\alpha P+\beta_{P}\left(R_{M t}-R_{R F t}\right)+e_{P t}
$$

dimana :

$$
\begin{array}{ll}
\alpha_{P} & =\text { differential return measure (alpha) } \\
\beta_{P} & =\text { slope persamaan garis hasil regresi linier (beta portofolio) } \\
R_{P \dagger} & =\text { pengembalian (return) reksadana pada periode } t \\
R_{F R t} & =\text { pengembalian (return) investasi bebas risiko pada periode } t \\
R_{M t} & =\text { pengembalian (return) portofolio pasar pada periode } t \text {, dimana: } \\
\qquad R_{M . t}=\frac{\mathrm{IHSG}_{\mathrm{t}}-\mathrm{IHSG}_{\mathrm{t}-1}}{\mathrm{IHSG}_{\mathrm{t}-1}}
\end{array}
$$




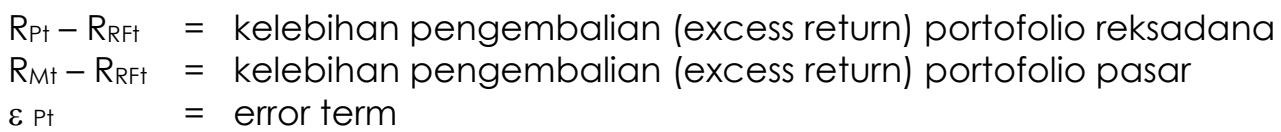

3. Untuk menghitung return portofolio pasar, return portofolio reksadana dan return investasi bebas risiko, dengan rumus:

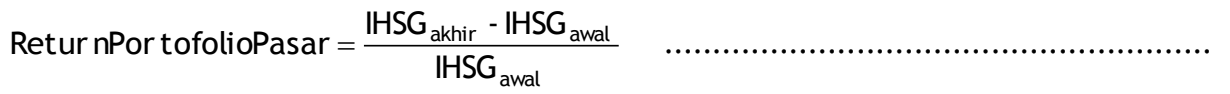

$$
\begin{aligned}
& \text { Retur nPor tofolioReksadana }=\frac{\mathrm{NAB} / \text { unit akhir }-\mathrm{NAB} / \text { unit awal }}{\mathrm{NAB} / \text { unit awal }} \\
& \text { Retur nInvestasiBebas Risiko }=\frac{\text { SukuBunga SBI Akhir }- \text { Suku Bunga SBI Awal }}{\text { SukuBunga SBI Awat }} \\
& \text { SukuBunga SBI Awal }
\end{aligned}
$$

Untuk reksadana, NAB (Nilai Aktiva Bersih) diperoleh melalui :

$$
N A B_{t}=\left(T_{N P}-T_{t} K_{t}\right) / J S B_{t}
$$

$$
\begin{array}{ll}
\text { dimana : } & \\
\mathrm{NAB}_{\dagger} & \text { : nilai aktiva bersih pada periode } \dagger \\
\mathrm{TNP}_{\dagger} & \text { : total nilai pasar portofolio pada periode } \dagger \\
\mathrm{TNK}_{\dagger} & : \text { total nilai kewajiban perusahaan pada periode }{ }^{\dagger} \\
\mathrm{JSB}_{\dagger} & : \text { jumlah saham yang beredar pada periode } \dagger
\end{array}
$$

Selanjutnya, berdasarkan nilai alpha $(\alpha)$ yang diperoleh dari model Jensen, disusun suatu kriteria (disebut sebagai kriteria Jensen alpha) sebagai berikut :

- Nilai alpha positif menunjukkan kinerja superior (outperform the market),

- Nilai alpha negatif menunjukkan kinerja inferior (underperform the market),

\section{- Nilai alpha nol menunjukkan kinerja yang proporsional dengan kinerja pasar}

Dari model Jensen juga akan diperoleh nilai beta $(\beta)$ yang merupakan koefisien regresi (slope) dari model tersebut. Nilai beta ini menunjukkan potensi pertumbuhan return (excess return) portofolio reksadana dibandingkan dengan potensi pertumbuhan return (excess return) portofolio pasar. Secara empirik nilai beta terbukti bias karena adanya faktor non-synchronous trading pada thin market, oleh karena itu perlu dikoreksi dengan menggunakan metode koreksi Fowler dan Rorke. 
Sebagai model awal koreksi, akan digunakan periode dua lags dan dua leads :

1. Operasi persamaan regresi berganda :

$$
\left(\mathrm{R}_{\mathrm{P}}-\mathrm{R}_{\mathrm{RF}}\right)_{\mathrm{t}}=\alpha_{\mathrm{P}}+\beta_{\mathrm{p}}^{-2}\left(\mathrm{R}_{\mathrm{M}}-\mathrm{R}_{\mathrm{RF}}\right)_{\mathrm{t}-2}+\beta_{\mathrm{P}}^{-1}\left(\mathrm{R}_{\mathrm{M}}-\mathrm{R}_{\mathrm{RF}}\right)_{\mathrm{t}-1}+\beta_{\mathrm{P}}^{0}\left(\mathrm{R}_{\mathrm{M}}-\mathrm{R}_{\mathrm{RF}}\right)_{\mathrm{t}}+\beta_{\mathrm{p}}^{+1}\left(\mathrm{R}_{\mathrm{M}}-\mathrm{R}_{\mathrm{RF}}\right)_{\mathrm{t}+1}+\beta_{\mathrm{p}}^{+2}\left(\mathrm{R}_{\mathrm{M}}-\mathrm{R}_{\mathrm{RF}}\right)_{\mathrm{t}+2}+\varepsilon_{\mathrm{Pt}} \quad \cdots
$$

2. Operasi persamaan regresi untuk memperoleh korelasi serial return indeks pasar dengan return indeks pasar periode sebelumnya :

$$
\left(\mathrm{R}_{\mathrm{M}}-\mathrm{R}_{\mathrm{RF}}\right)_{\mathrm{t}}=\alpha+\rho_{1}\left(\mathrm{R}_{\mathrm{M}}-\mathrm{R}_{\mathrm{RF}}\right)_{\mathrm{t}-1}+\rho_{2}\left(\mathrm{R}_{\mathrm{M}}-\mathrm{R}_{\mathrm{RF}}\right)_{\mathrm{t}-2}+\varepsilon_{\mathrm{Pt}}
$$

3. Menentukan bobot yang digunakan:

$$
\begin{aligned}
& W_{1}=\frac{1+2 \rho_{1}+\rho_{2}}{1+2 \rho_{1}+2 \rho_{2}} \\
& W_{2}=\frac{1+\rho_{1}+\rho_{2}}{1+2 \rho_{1}+2 \rho_{2}}
\end{aligned}
$$

4. Menentukan beta dikoreksi yang merupakan penjumlahan koefisien regresi berganda dengan bobot :

$$
\beta_{\rho}=W_{2} \beta_{P}^{-2}+W_{1} \beta_{P}^{-1}+\beta_{P}{ }^{0}+W_{1} \beta_{P}^{+1}+W_{2} \beta_{P}^{+2}
$$

Berdasarkan nilai unbiased beta yang telah diperoleh, maka dapat diketahui potensi pertumbuhan return portofolio reksadana dengan kriteria sebagai berikut :

- $\quad$ Beta $>$ 1, menunjukkan potensi pertumbuhan return portofolio reksadana lebih besar daripada return portofolio pasar

- Beta $=1$, menunjukkan potensi pertumbuhan return portofolio reksadana sama dengan return portofolio pasar

- Beta < 1, menunjukkan potensi pertumbuhan return portofolio reksadana lebih kecil daripada return portofolio pasar

\section{Hasil dan Pembahasan}

Analisis Kinerja Portofolio Reksadana Saham

Berdasarkan uraian dalam bab sebelumnya, disebutkan bahwa portofolio yang telah terdiversifikasi cukup mempertimbangkan risiko sistematik atau risiko pasar saja karena lebih relevan dalam pengukuran kinerja portofolio. Berdasarkan hal tersebut, 
maka sebelum mengukur kinerja portofolio reksadana saham, terlebih dahulu akan diukur derajat diversifikasi portofolio. Untuk mengukur derajat diversifikasi portofolio tersebut digunakan alat ukur koefisien determinasi atau $\mathrm{R}^{2}$. Semakin terdiversifikasi suatu portofolio, nilai $R^{2}$ akan semakin mendekati 1,0. Nilai $R^{2}$ sebesar 1,0 menunjukkan bahwa return (excess return) portofolio reksadana sepenuhnya dapat dijelaskan oleh return (excess return) portofolio pasar, atau dapat dikatakan bahwa return (excess return) portofolio reksadana tersebut identik dengan return (excess return) portofolio pasar.

Adapun hasil pengukuran tersebut dapat dilihat pada tabel berikut :

Tabel 5

Derajat Diversifikasi Setiap Portofolio Reksadana Saham Per Tahun Selama Periode 1 Januari 2002-31 Desember 2006

\begin{tabular}{clccccc}
\hline \multirow{2}{*}{ No } & \multirow{2}{*}{ Reksadana Saham } & \multicolumn{5}{c}{ Koefisien Determinasi $\left(\mathrm{r}^{2}\right)$} \\
\cline { 3 - 6 } & & 2002 & 2003 & 2004 & 2005 & 2006 \\
\hline 1 & Bahana Dana Prima & 0.930 & 0.866 & 0.968 & 0.979 & 0.899 \\
2 & Big Nusantara & 0.941 & 0.777 & 0.875 & $0.444^{*}$ & 0.768 \\
3 & BNI Dana Berkembang & 0.562 & 0.563 & 0.771 & 0.957 & 0.830 \\
4 & Panin Dana Maksima & 0.781 & 0.849 & 0.930 & 0.927 & 0.951 \\
5 & Phinisi Dana Saham & 0.988 & 0.855 & 0.960 & $0.334^{*}$ & 0.956 \\
6 & Rencana Cerdas & 0.956 & 0.917 & 0.905 & $0.000^{*}$ & 0.964 \\
7 & Schroder Dana Prestasi Plus & 0.838 & 0.786 & 0.930 & 0.980 & 0.989 \\
\hline
\end{tabular}

Ket. ${ }^{*}$ : derajat diversifikasi $<0.500$

Dari tabel 5, dapat diketahui bahwa selama periode 1 Januari 2002-31 Desember 2006, hampir seluruh portofolio reksadana saham telah cukup terdiversifikasi (indikator : koefisien determinasi yang cukup tinggi, hampir mendekati satu atau lebih dari 0,50), kecuali Big Nusantara, Phinisi Dana Saham dan Rencana Cerdas pada tahun 2005. Tidak optimalnya tingkat diversifikasi portofolio reksadana ini dapat disebabkan pada reksadana saham tidak semua dana investasi dialokasikan pada efek jenis saham saja, tetapi ada beberapa persen dana yang dialokasikan pada surat berharga lain, seperti efek jenis hutang (obligasi) dan deposito. Namun secara keseluruhan, nilai koefisien determinasi berada di atas 0,50. Hal ini berarti bahwa portofolio reksadana dipengaruhi oleh portofolio pasar atau bahwa portofolio pasar mampu menjelaskan portofolio reksadana dengan baik. Oleh karena itu, maka dalam mengukur kinerja masing-masing portofolio, model Jensen cukup relevan untuk digunakan. Melalui model pengukuran kinerja Jensen (Jensen Portfolio Performance Measure), dapat diketahui bagaimana kinerja dari masingmasing portofolio reksadana tersebut, dengan nilai konstanta (alpha- $\alpha$ ) sebagai indikatornya.

Berikut adalah ringkasan dari hasil pengolahan data (berdasarkan program SPSS versi 15) yang menunjukkan kinerja dari setiap reksadana saham berdasarkan model Jensen : 
Tabel 6

Kinerja Setiap Portofolio Reksadana Saham Per Tahun Selama Periode 1 Januari 2002 - 31 Desember 2006

\begin{tabular}{clccccc}
\hline \multirow{2}{*}{ No } & \multirow{2}{*}{ Reksadana Saham } & \multicolumn{5}{c}{ Konstanta $(\alpha)$} \\
\cline { 3 - 7 } & & 2002 & 2003 & 2004 & \multicolumn{1}{c}{2005} & 2006 \\
\hline 1 & Bahana Dana Prima & 0.0082 & 0.0097 & -0.0024 & -0.0019 & 0.0071 \\
2 & Big Nusantara & 0.0023 & -0.0011 & $-0.0196^{*}$ & -0.0263 & $-0.0350^{*}$ \\
3 & BNI Dana Berkembang & 0.0029 & 0.0087 & -0.0083 & -0.0007 & 0.0174 \\
4 & Panin Dana Maksima & 0.0125 & 0.0164 & -0.0049 & 0.0061 & $0.0190^{*}$ \\
5 & Phinisi Dana Saham & -0.0000 & 0.0035 & -0.0011 & 0.0081 & 0.0103 \\
6 & Rencana Cerdas & 0.0063 & 0.0081 & 0.0115 & -0.0198 & 0.0050 \\
7 & Schroder Dana Prestasi & 0.0171 & 0.0127 & 0.0126 & 0.0015 & 0.0051 \\
& Plus & & & & & \\
\hline
\end{tabular}

Ket. ${ }^{*}$ : signifikan pada $\alpha=0.05$

Berdasarkan tabel 6, dengan indikator nilai alpha ( $\alpha$ ) positif (+) dan negatif (-) dapat diketahui bahwa : (1) Selama tahun 2002, seluruh portofolio reksadana saham memiliki kinerja di atas portofolio pasar, kecuali Phinisi Dana Saham, (2) Selama tahun 2003, seluruh portofolio reksadana saham memiliki kinerja di atas portofolio pasar, kecuali Big Nusantara, (3) Selama tahun 2004, hampir seluruh portofolio reksadana saham memiliki kinerja di bawah portofolio pasar, kecuali Rencana Cerdas dan Schroder Dana Prestasi Plus, (4) Selama tahun 2005, sebagian besar portofolio reksadana saham memiliki kinerja di bawah portofolio pasar, kecuali Panin Dana Maksima, Phinisi Dana Saham dan Schroder Dana Prestasi Plus, (5) Selama tahun 2006, hampir seluruh portofolio reksadana saham memiliki kinerja di atas portofolio pasar, kecuali Big Nusantara.

Analisis Kinerja Per Lima Tahun

Seperti halnya pada pengukuran kinerja reksadana per tahun, maka dalam pengukuran kinerja per lima tahun-nya, terlebih dahulu akan diukur derajat diversifikasi portofolio dengan indikator koefisien determinasi. Hasil pengukuran tersebut dapat dilihat pada tabel berikut :

Tabel 7

Derajat Diversifikasi Setiap Portofolio Reksadana Saham Per Lima Tahun Selama Periode 1 Januari 2002-31 Desember 2006

\begin{tabular}{clc}
\hline No & \multicolumn{1}{c}{ Reksadana Saham } & Koefisien Determinasi $\left(r^{2}\right)$ \\
\hline 1 & Bahana Dana Prima & 0.944 \\
2 & Big Nusantara & 0.742 \\
3 & BNI Dana Berkembang & 0.770 \\
4 & Panin Dana Maksima & 0.899 \\
5 & Phinisi Dana Saham & 0.734 \\
6 & Rencana Cerdas & 0.541 \\
7 & Schroder Dana Prestasi Plus & 0.911 \\
\hline
\end{tabular}


Dari tabel 7, dapat diketahui bahwa selama periode 1 Januari 2002-31 Desember 2006, seluruh portofolio reksadana saham telah cukup terdiversifikasi (indikator : koefisien determinasi yang cukup tinggi, hampir mendekati satu atau lebih dari 0,50 ). Hal ini berarti bahwa portofolio reksadana dipengaruhi oleh portofolio pasar atau bahwa portofolio pasar mampu menjelaskan portofolio reksadana dengan baik. Oleh karena itu, maka dalam mengukur kinerja masing-masing portofolio, model Jensen cukup relevan untuk digunakan.

Berikut adalah ringkasan dari hasil pengolahan data (berdasarkan program SPSS versi 15) yang menunjukkan kinerja setiap reksadana berdasarkan model Jensen:

Tabel 8

Kinerja Setiap Portofolio Reksadana Saham Per Lima Tahun Selama Periode 1 Januari 2002-31Desember 2006

\begin{tabular}{clc}
\hline No & Reksadana & Konstanta $(\alpha)$ \\
1 & Bahana Dana Prima & 0.0018 \\
2 & Big Nusantara & -0.0155 \\
3 & BNI Dana Berkembang & -0.0024 \\
4 & Panin Dana Maksima & $0.0073^{*}$ \\
5 & Phinisi Dana Saham & 0.0055 \\
6 & Rencana Cerdas & 0.0149 \\
7 & Schroder Dana Prestasi Plus & $0.0080^{*}$ \\
\hline
\end{tabular}

Ket. ${ }^{*}$ : signifikan pada $\alpha=0.05$

Konstanta pada tabel 8 merupakan indikator kinerja portofolio reksadana atau disebut sebagai Jensen Alpha. Berdasarkan nilai konstanta tersebut dapat diketahui bahwa selama periode 1 Januari 2002 - 31 Desember 2006 : (1) Reksadana Bahana Dana Prima memiliki kinerja superior (outperform the market) yang terlihat dari nilai konstanta sebesar 0.001853, yang berarti bahwa kinerja reksadana Bahana Dana Prima $0.1853 \%$ lebih tinggi daripada kinerja portofolio pasar, (2) Reksadana Big Nusantara memiliki kinerja inferior (underperform the market) yang terlihat dari nilai konstanta sebesar -0.01551 , yang berarti bahwa kinerja reksadana Big Nusantara $1.551 \%$ lebih rendah daripada kinerja portofolio pasar, (3) Reksadana BNI Dana Berkembang memiliki kinerja inferior (underperform the market, (4) Reksadana Panin Dana Maksima, Phinisi Dana Saham, Rencana Cerdas, dan Schroder Dana Prestasi Plus memiliki kinerja superior (outperform the market).

Adapun berdasarkan hasil analisis yang dilakukan, baik per tahun maupun per lima tahun, sebagian besar kinerja portofolio reksadana ternyata tidak signifikan. Tidak signifikannya kinerja tersebut dapat disebabkan karena dalam rangka memaksimalkan dana investor, manajer investasi harus sering mengubah komposisi portofolionya, sehingga jenis dan jumlah saham dalam portofolio juga menjadi sering berubah (Cahyono, 2002). Perubahan ini akan berpengaruh terhadap kinerja reksadana yang perhitungannya didasarkan atas return-nya. (Utomo dan Nugraha, 2002 ; Cahyono, 2002). Setiap perubahan dalam komposisi portofolio yang 
dilakukan oleh manajer investasi dapat merefleksikan bagaimana kemampuan manajer investasi dalam memilih sekuritas yang tepat (security selection ability) dan pada saat yang tepat (market timing ability). (Reily dan Brown, 2003).

Superioritas kinerja beberapa reksadana dapat disebabkan oleh beberapa alasan, yaitu : (1) Semakin maraknya aktivitas investasi pada instrumen reksadana pasca booming reksadana tahun 2000, (2) Saham-saham dalam portofolio reksadana pada umumnya merupakan saham-saham yang tingkat likuiditasnya tinggi dan mendominasi volume perdagangan di BEJ, seperti saham-saham LQ 45, (3) Dana kelolaan manajer investasi reksadana saham tidak seluruhnya diinvestasikan pada efek saham, tetapi ada beberapa persen (maksimal 20\% dari dana kelolaan) diinvestasikan pada efek lain seperti obligasi dan deposito, serta (4) Kombinasi gaya manajemen aktif dan pasif yang diterapkan oleh manajer investasi.

\section{Analisis Kinerja Portofolio Reksadana Campuran}

Sebagaimana halnya pada portofolio reksadana saham, maka dalam mengukur kinerja portofolio reksadana campuran, terlebih dahulu akan diukur derajat diversifikasi portofolio dengan menggunakan indikator koefisien determinasi.

Hasil pengukuran tersebut adalah sebagai berikut :

Tabel 9

Derajat Diversifikasi Setiap Portofolio Reksadana Campuran Per Tahun Selama Periode 1 Januari 2002-31 Desember 2006

\begin{tabular}{cllllll}
\hline \multirow{2}{*}{ No } & \multirow{2}{*}{ Reksadana Saham } & \multicolumn{5}{c}{ Koefisien Determinasi $\left(r^{2}\right)$} \\
\cline { 3 - 6 } & 2002 & 2003 & 2004 & 2005 & 2006 \\
\hline 1 & Anggrek & 0.857 & 0.744 & 0.865 & 0.948 & 0.835 \\
2 & Bahana Dana Infrastruktur & 0.818 & 0.577 & 0.813 & 0.960 & 0.825 \\
3 & Bahana Dana Selaras & 0.761 & $0.225^{*}$ & 0.894 & 0.972 & 0.849 \\
4 & Mahanusa Dana Kapital & 0.580 & $0.003^{*}$ & 0.798 & 0.944 & 0.915 \\
5 & Master Berimbang & $0.042^{*}$ & 0.612 & 0.813 & 0.923 & 0.900 \\
6 & PNM Syariah & $0.273^{*}$ & $0.071^{*}$ & $0.128^{*}$ & 0.860 & 0.756 \\
7 & Sam Berkembang & $0.196^{*}$ & 0.661 & 0.871 & 0.891 & 0.877 \\
8 & Schroder Dana Prestasi & 0.930 & $0.298^{*}$ & 0.908 & 0.975 & 0.988 \\
9 & Schroder Dana Terpadu & 0.888 & 0.439 & 0.866 & 0.961 & 0.979 \\
10 & Simas Satu & 0.511 & $0.294^{*}$ & 0.759 & 0.890 & 0.775 \\
11 & Syariah Berimbang & 0.882 & $0.008^{*}$ & 0.745 & 0.918 & 0.911 \\
\hline
\end{tabular}

Ket. * : derajat diversifikasi $<0.500$

Dari tabel 9, dapat diketahui bahwa selama periode 1 Januari 2002-31 Desember 2006, hampir seluruh portofolio reksadana saham telah cukup terdiversifikasi (indikator: koefisien determinasi yang cukup tinggi, hampir mendekati satu atau lebih dari 0,50), kecuali Master Berimbang, PNM Syariah dan Sam Berkembang (masing-masing untuk tahun 2002), Bahana Dana Selaras, Mahanusa Dana Kapital, 
PNM Syariah, Schroder Dana Prestasi, Simas Satu dan Syariah Berimbang (masingmasing untuk tahun 2003), PNM Syariah (tahun 2004).

Adapun tidak optimalnya tingkat diversifikasi beberapa portofolio ini dapat disebabkan karena pada reksadana campuran, proporsi alokasi dana investasi berbeda-beda, sesuai dengan pengertian dari reksadana campuran, yaitu reksadana yang melakukan investasi dalam efek bersifat ekuitas dan bersifat utang, dengan perbandingan (proporsi alokasi investasi) yang tidak termasuk reksadana pendapatan tetap dan reksadana saham. Dengan demikian, ada kemungkinan bahwa pada portofolio-portofolio yang tidak terdiversifikasi secara sempurna tersebut, dana investasi lebih banyak dialokasikan pada efek utang (obligasi) atau instrumen pasar vang.

Adapun secara keseluruhan, nilai koefisien determinasi portofolio reksadana campuran berada di atas 0,50 . Hal ini berarti bahwa portofolio reksadana dipengaruhi oleh portofolio pasar atau bahwa portofolio pasar mampu menjelaskan portofolio reksadana dengan baik. Oleh karena itu, maka dalam mengukur kinerja masing-masing portofolio, model Jensen cukup relevan untuk digunakan.

Berikut adalah ringkasan dari hasil pengolahan data (berdasarkan program SPSS versi 15) yang menunjukkan kinerja dari setiap reksadana campuran berdasarkan model Jensen:

Tabel 10

Kinerja Setiap Portofolio Reksadana Campuran Per Tahun Selama Periode 1 Januari 2002-31Desember 2006

\begin{tabular}{|c|c|c|c|c|c|c|}
\hline \multirow{2}{*}{ No } & \multirow{2}{*}{ Reksadana Saham } & \multicolumn{5}{|c|}{ Konstanta (a) } \\
\hline & & 2002 & 2003 & 2004 & 2005 & 2006 \\
\hline 1 & Anggrek & $0.0163^{*}$ & 0.0234 & 0.0045 & -0.0093 & 0.0124 \\
\hline 2 & Bahana Dana Infrastruktur & 0.0156 & 0.0017 & 0.0028 & $-0.0140 *$ & 0.0124 \\
\hline 3 & Bahana Dana Selaras & $0.0199 *$ & -0.0553 & 0.0061 & $-0.0129 *$ & 0.0153 \\
\hline 4 & Mahanusa Dana Kapital & -0.1220 & $0.0795^{*}$ & -0.0036 & -0.0031 & 0.0159 \\
\hline 5 & Master Berimbang & -0.0070 & -0.0022 & -0.0117 & -0.0024 & 0.0102 \\
\hline 6 & PNM Syariah & 0.0107 & -0.1050 & 0.0168 & $-0.0172 *$ & $0.0195^{*}$ \\
\hline 7 & Sam Berkembang & -0.0069 & -0.0028 & 0.0129 & -0.0088 & 0.0070 \\
\hline 8 & Schroder Dana Prestasi & 0.0126 & -0.0430 & 0.0123 & -0.0027 & 0.0010 \\
\hline 9 & Schroder Dana Terpadu & $0.0220 *$ & -0.0119 & $0.0153^{*}$ & -0.0089 & $0.0070^{*}$ \\
\hline 10 & Simas Satu & 0.0273 & -0.0011 & -0.0038 & -0.0129 & -0.0032 \\
\hline 11 & Syariah Berimbang & $0.0108^{*}$ & 0.1230 & 0.0052 & -0.0128 & 0.0108 \\
\hline
\end{tabular}

Ket. ${ }^{*}$ : signifikan pada $\alpha=0.05$

Berdasarkan tabel 10, dengan indikator nilai alpha (a) positif $(+)$ dan negatif $(-)$ dapat diketahui bahwa : (1) Selama tahun 2002, hampir seluruh portofolio reksadana campuran memiliki kinerja di atas portofolio pasar, kecuali Mahanusa Dana Kapital, Master Berimbang, dan Sam Berkembang, (2) Selama tahun 2003, hampir seluruh portofolio reksadana campuran memiliki kinerja di bawah portofolio 
pasar, kecuali Anggrek, Bahana Dana Infrastruktur, Mahanusa Dana Kapital, dan Syariah Berimbang, (3) Selama tahun 2004, hampir seluruh portofolio reksadana campuran memiliki kinerja di atas portofolio pasar, kecuali Mahanusa Dana Kapital, Master Berimbang dan Simas Satu, (4) Selama tahun 2005, seluruh portofolio reksadana campuran memiliki kinerja di bawah portofolio pasar, (5) Selama tahun 2006, hampir seluruh portofolio reksadana campuran memiliki kinerja di atas portofolio pasar, kecuali Simas Satu.

Seperti halnya pada pengukuran kinerja reksadana per tahun, maka dalam pengukuran kinerja per lima tahun-nya, terlebih dahulu akan diukur derajat diversifikasi portofolio dengan indikator koefisien determinasi. Hasil pengukuran tersebut dapat dilihat pada tabel berikut :

Tabel 11

Derajat Diversifikasi Setiap Portofolio Reksadana Campuran Per Lima Tahun Selama Periode 1 Januari 2002-31 Desember 2006

\begin{tabular}{cll}
\hline No & \multicolumn{1}{c}{ Reksadana Campuran } & Koefisien Determinasi $\left(\mathrm{r}^{2}\right)$ \\
\hline 1 & Anggrek & 0.874 \\
2 & Bahana Dana Infrastruktur & 0.802 \\
3 & Bahana Dana Selaras & $0.304^{*}$ \\
4 & Mahanusa Dana Kapital & 0.846 \\
5 & Master Berimbang & 0.512 \\
6 & PNM Syariah & $0.000^{*}$ \\
7 & Sam Berkembang & $0.056^{*}$ \\
8 & Schroder Dana Prestasi & $0.483^{*}$ \\
9 & Schroder Dana Terpadu & 0.703 \\
10 & Simas Satu & 0.559 \\
11 & Syariah Berimbang & $0.095^{*}$ \\
\hline Ket. & . Serajat diversifikasi< $<0.500$ &
\end{tabular}

Ket. $^{*}$ : derajat diversifikasi $<0.500$

Dari tabel 11, dapat diketahui bahwa selama periode 1 Januari 2002-31 Desember 2006, seluruh portofolio reksadana campuran telah cukup terdiversifikasi, dengan indikator koefisien determinasi yang cukup tinggi, hampir mendekati satu atau lebih dari 0,50, kecuali Bahana Dana Selaras, PNM Syariah, Sam Berkembang, Schroder Dana Prestasi dan Syariah Berimbang. Hal ini berarti bahwa model Jensen kurang relevan untuk digunakan dalam mengukur kinerja per lima tahun dari kelima portofolio tersebut. Dengan demikian, dalam uraian berikut hanya akan dianalisis kinerja dari portofolio-portofolio yang relevan saja, sebagaimana yang terdapat dalam tabel berikut: 
Tabel 12

Kinerja Setiap Portofolio Reksadana Campuran Per Lima Tahun Selama Periode 1 Januari 2002-31 Desember 2006

\begin{tabular}{clc}
\hline No & \multicolumn{1}{c}{ Reksadana } & $\begin{array}{c}\text { Konstanta } \\
(\alpha)\end{array}$ \\
\hline 1 & Anggrek & 0.0045 \\
2 & Bahana Dana Infrastruktur & 0.0006 \\
3 & Mahanusa Dana Kapital & 0.0004 \\
4 & Master Berimbang & -0.0015 \\
5 & Schroder Dana Terpadu & 0.0047 \\
6 & Simas Satu & 0.0014 \\
\hline
\end{tabular}

Berdasarkan tabel 12, analisis kinerja setiap portofolio reksadana campuran selama periode 1 Januari 2002 - 31 Desember 2006 adalah sebagai berikut : (1) Reksadana Anggrek, Bahana Dana Infrastruktur, Mahanusa Dana Kapital, Schroder Dana Terpadu, dan Simas Satu, memiliki kinerja superior (outperform the market, (2) Reksadana Master Berimbang memiliki kinerja inferior (underperform the market).

Adapun berdasarkan hasil analisis yang dilakukan, baik per tahun maupun per lima tahun, hampir semua nilai kinerja portofolio reksadana campuran tidak signifikan. Sebagaimana halnya pada portofolio reksadana saham, tidak signifikannya kinerja tersebut dapat disebabkan karena manajer investasi sering mengubah komposisi portofolionya, sehingga jenis dan jumlah efek dalam portofolio reksadana campuran juga menjadi sering berubah.

Adapun superioritas kinerja beberapa reksadana campuran dapat disebabkan oleh karena ada kemungkinan bahwa pada periode tersebut, alokasi dana investasi banyak dialokasikan pada saham, khususnya saham-saham unggulan yang memiliki tingkat likuiditas yang tinggi, seperti saham-saham LQ 45. Selain itu, alokasi dana pada efek jenis utang dan instrumen pasar vang juga dapat menyebabkan kinerja portofolio menjadi lebih tinggi dibandingkan dengan kinerja portofolio pasar (proxy: IHSG).

\section{Analisis Potensi Pertumbuhan Return Portofolio Reksadana Saham}

Tabel berikut ini menunjukkan potensi pertumbuhan return setiap portofolio reksadana saham per tahun dengan indikator nilai beta ( $\beta$ ) yang merupakan koefisien regresi dari model Jensen dan mereflekskan risiko sistematik atau risiko pasar yang dihadapi oleh portofolio: 
Tabel 13

Potensi Pertumbuhan Return Setiap Portofolio Reksadana Saham Per Tahun Selama Periode 1 Januari 2002-31 Desember 2006

\begin{tabular}{clccccc}
\hline \multirow{2}{*}{ No } & \multirow{2}{*}{ Reksadana Saham } & \multicolumn{5}{c}{ Koefisien Regresi $(\beta)$} \\
\cline { 3 - 6 } & 2002 & 2003 & 2004 & 2005 & 2006 \\
\hline 1 & Bahana Dana Prima & 0.935 & 0.939 & 1.114 & 1.061 & 0.906 \\
2 & Big Nusantara & 0.758 & 0.805 & 0.766 & 0.710 & 0.807 \\
3 & BNI Dana Berkembang & 0.760 & 0.756 & 0.965 & 1.107 & 0.645 \\
4 & Panin Dana Maksima & 0.826 & 0.805 & 0.990 & 0.963 & 0.811 \\
5 & Phinisi Dana Saham & 1.185 & 1.023 & 1.061 & 0.904 & 0.869 \\
6 & Rencana Cerdas & 1.011 & 0.923 & 0.896 & $0.001^{*}$ & 0.941 \\
7 & Schroder Dana Prestasi Plus & 1.012 & 0.947 & 0.913 & 1.002 & 0.935 \\
\hline
\end{tabular}

Ket. ${ }^{*}$ : tidak signifikan pada $\alpha=0.05$

Penelitian-penelitian sebelumnya menyebutkan bahwa nilai beta pada pasar modal di negara-negara berkembang seperti Indonesia cenderung bias karena adanya faktor non-synchronous trading. Oleh karena itu, untuk menguji akurasi nilai beta pada tabel 4.9, akan dilakukan koreksi berdasarkan model Fowler dan Rorke. Hasil pengujian tersebut adalah diperolehnya nilai beta yang tidak bias (unbiased beta), sebagaimana yang terdapat pada tabel berikut :

Tabel 14

Potensi Pertumbuhan Return (Un-biased Beta)

Setiap Portofolio Reksadana Saham Per Tahun

Selama Periode 1 Januari 2002-31 Desember 2006

\begin{tabular}{cllcccl}
\hline \multirow{2}{*}{ No } & \multirow{2}{*}{ Reksadana Saham } & \multicolumn{5}{c}{ Unbiased Beta } \\
\cline { 3 - 7 } & & \multicolumn{1}{c}{2002} & 2003 & 2004 & \multicolumn{1}{c}{2005} \\
\hline 1 & Bahana Dana Prima & 0.935 & 0.939 & 1.114 & 1.061 & 0.906 \\
2 & Big Nusantara & $0.898^{* *}$ & 0.805 & 0.766 & 0.710 & 0.807 \\
3 & BNI Dana Berkembang & $1.162^{*}$ & 0.756 & 0.965 & $0.950^{* *}$ & $0.669^{*}$ \\
4 & Panin Dana Maksima & $0.917^{* *}$ & 0.805 & 0.990 & $1.020^{*}$ & $0.867^{*}$ \\
5 & Phinisi Dana Saham & $1.169^{* *}$ & 1.023 & 1.061 & 0.904 & 0.869 \\
6 & Rencana Cerdas & 1.011 & $1.033^{*}$ & 0.896 & $0.150^{*}$ & $0.950^{*}$ \\
7 & Schroder Dana Prestasi Plus & 1.012 & 0.947 & 0.913 & 1.002 & 0.935 \\
\hline
\end{tabular}

Ket. $^{*}$ : : dikoreksi dengan 1 periode lag dan lead

Ket. ${ }^{* *}$ : dikoreksi dengan 2 periode lag dan lead

Berdasarkan tabel 14, dapat diketahui bahwa: (1) Selama tahun 2002, sebagian besar portofolio reksadana saham memiliki potensi pertumbuhan return di atas pertumbuhan return portofolio pasar, kecuali Bahana Dana Berkembang, Big Nusantara, dan Panin Dana Maksima, (2) Selama tahun 2003, hampir seluruh portofolio reksadana saham memiliki potensi pertumbuhan return di bawah pertumbuhan return portofolio pasar, kecuali Phinisi Dana Saham dan Rencana Cerdas, (3) Selama tahun 2004, hampir seluruh portofolio reksadana saham memiliki potensi pertumbuhan return di bawah pertumbuhan return portofolio pasar, kecuali 
Bahana Dana Prima dan Phinisi Dana Saham, (4) Selama tahun 2005, sebagian besar portofolio reksadana saham memiliki potensi pertumbuhan return di bawah pertumbuhan return portofolio pasar, kecuali Bahana Dana Prima, Panin Dana Maksima, dan Schroder Dana Prestasi Plus, (5) Selama tahun 2006, seluruh portofolio reksadana saham memiliki potensi pertumbuhan return di bawah pertumbuhan return portofolio pasar.

Tabel berikut ini menunjukkan potensi pertumbuhan return portofolio reksadana saham per lima tahun dengan indikator nilai beta ( $\beta$ ) yang merupakan koefisien regresi dari model Jensen dan mereflekskan risiko sistematik atau risiko pasar yang dihadapi oleh portofolio :

Tabel 15

Potensi Pertumbuhan Return Setiap Portofolio Reksadana Saham Per Lima Tahun Selama Periode 1 Januari 2002-31 Desember 2006

\begin{tabular}{clc}
\hline No & \multicolumn{1}{c}{ Reksadana } & Koefisien Regresi \\
& \multicolumn{1}{c}{$(\beta)$} \\
\hline 1 & Bahana Dana Prima & $1.007^{*}$ \\
2 & Big Nusantara & $0.794^{*}$ \\
3 & BNI Dana Berkembang & $0.880^{*}$ \\
4 & Panin Dana Maksima & $0.895^{*}$ \\
5 & Phinisi Dana Saham & $0.996^{*}$ \\
6 & Rencana Cerdas & $0.761^{*}$ \\
7 & Schroder Dana Prestasi Plus & $0.987^{*}$ \\
\hline
\end{tabular}

Ket. ${ }^{*}$ : signifikan pada $\alpha=0.05$

Analisis dari masing-masing portofolio reksadana saham sebagaimana yang terdapat dalam tabel 15, adalah sebagai berikut : (1) Nilai koefisien regresi reksadana Bahana Dana Prima adalah sebesar 1.007, hal ini berarti bahwa potensi pertumbuhan return reksadana Bahana Dana Prima adalah sebesar 0.007 atau $0.70 \%$ di atas pertumbuhan return pasar, (2) Nilai koefisien regresi reksadana Big Nusantara adalah sebesar 0.794, hal ini berarti bahwa potensi pertumbuhan return reksadana Big Nusantara adalah sebesar 0.206 atau $20.06 \%$ di bawah pertumbuhan return pasar, (3) Sebagaimana Big Nusantara, reksadana BNI Dana Berkembang, Panin Dana Maksima, Phinisi Dana Saham, Rencana Cerdas, dan Schroder Dana Prestasi Plus memiliki potensi pertumbuhan return bawah pertumbuhan return pasar.

\section{Analisis Potensi Pertumbuhan Return Portofolio Reksadana Campuran}

Tabel berikut ini menunjukkan potensi pertumbuhan return setiap portofolio reksadana campuran per tahun dengan indikator nilai beta $(\beta)$ yang merupakan koefisien regresi dari model Jensen dan mereflekskan risiko sistematik atau risiko pasar yang dihadapi oleh portofolio : 
Tabel 16

Potensi Pertumbuhan Return Setiap Portofolio Reksadana Campuran Per Tahun Selama Periode 1 Januari 2002-31 Desember 2006

\begin{tabular}{clccccc}
\hline \multirow{2}{*}{ No } & \multirow{2}{*}{ Reksadana Campuran } & \multicolumn{5}{c}{ Koefisien Regresi $(\beta)$} \\
\cline { 3 - 6 } & & 2002 & 2003 & 2004 & 2005 & 2006 \\
\hline 1 & Anggrek & 0.602 & 0.540 & 0.679 & 0.805 & 0.725 \\
2 & Bahana Dana Infrastruktur & 0.545 & 0.894 & 0.701 & 0.907 & 0.800 \\
3 & Bahana Dana Selaras & 0.471 & $1.910^{*}$ & 0.649 & 0.844 & 0.715 \\
4 & Mahanusa Dana Kapital & 2.638 & $-0.019^{*}$ & 0.862 & 0.974 & 0.970 \\
5 & Master Berimbang & $0.247^{*}$ & 1.062 & 0.816 & 0.774 & 0.656 \\
6 & PNM Syariah & $-1.811^{*}$ & $1.084^{*}$ & $-0.786^{*}$ & 0.580 & 0.382 \\
7 & Sam Berkembang & $-1.539^{*}$ & 1.005 & 0.682 & 0.989 & 0.724 \\
8 & Schroder Dana Prestasi & 0.908 & $1.815^{*}$ & 0.830 & 0.938 & 0.972 \\
9 & Schroder Dana Terpadu & 0.701 & 1.080 & 0.628 & 0.791 & 0.652 \\
10 & Simas Satu & 0.291 & $0.846^{*}$ & 0.652 & 0.712 & 0.759 \\
11 & Syariah Berimbang & 0.405 & $-0.374^{*}$ & 0.475 & 0.757 & 0.687 \\
\hline
\end{tabular}

Ket. ${ }^{*}$ : tidak signifikan pada $\alpha=0.05$

Seperti halnya reksadana saham, maka untuk menguji akurasi nilai beta pada tabel 16, akan dilakukan koreksi berdasarkan model Fowler dan Rorke, sebagaimana yang terdapat pada tabel berikut :

Tabel 17

Potensi Pertumbuhan Return (Un-biased Beta) Setiap Portofolio Reksadana Campuran Per Tahun Selama Periode 1 Januari 2002-31 Desember 2006

\begin{tabular}{cllllll}
\hline \multirow{2}{*}{ No } & \multirow{2}{*}{ Reksadana Saham } & \multicolumn{5}{c}{ Un-biased Beta } \\
\cline { 3 - 7 } & & \multicolumn{1}{c}{2002} & \multicolumn{1}{c}{2003} & \multicolumn{1}{c}{2004} & \multicolumn{1}{c}{2005} & \multicolumn{1}{c}{2006} \\
\hline 1 & Anggrek & 0.602 & 0.540 & 0.679 & $0.881^{*}$ & 0.725 \\
2 & Bahana Dana Infrastruktur & $0.811^{*}$ & 0.894 & $1.015^{*}$ & 0.907 & 0.800 \\
3 & Bahana Dana Selaras & 0.471 & $1.910^{*}$ & 0.649 & $0.874^{*}$ & 0.715 \\
4 & Mahanusa Dana Kapital & 2.638 & $1.064^{*}$ & $1.068^{*}$ & $1.022^{* *}$ & 0.970 \\
5 & Master Berimbang & $1.060^{*}$ & 1.062 & 0.816 & 0.774 & 0.656 \\
6 & PNM Syariah & $0.299^{*}$ & $1.084^{*}$ & $0.500^{*}$ & $0.709^{*}$ & $0.607^{*}$ \\
7 & Sam Berkembang & $0.787^{*}$ & 1.005 & 0.682 & 0.989 & $0.743^{*}$ \\
8 & Schroder Dana Prestasi & 0.908 & $1.884^{* *}$ & 0.830 & 0.990 & 0.972 \\
9 & Schroder Dana Terpadu & 0.701 & 1.080 & 0.628 & $0.851^{* *}$ & $0.733^{*}$ \\
10 & Simas Satu & 0.291 & $1.037^{* *}$ & $0.749^{* *}$ & $0.714^{*}$ & $1.067^{* *}$ \\
11 & Syariah Berimbang & 0.405 & $0.911^{* *}$ & 0.475 & $0.808^{*}$ & 0.687 \\
\hline
\end{tabular}

Ket. * : dikoreksi dengan 1 periode lag dan lead

Ket. ${ }^{* *}$ : dikoreksi dengan 2 periode lag dan lead

Berdasarkan tabel 17, dapat diketahui bahwa: (1) Selama tahun 2002, hampir seluruh portofolio reksadana campuran memiliki potensi pertumbuhan return di bawah pertumbuhan return portofolio pasar, kecuali Mahanusa Dana Kapital dan 
Master Berimbang, (2) Selama tahun 2003, hampir seluruh portofolio reksadana campuran memiliki potensi pertumbuhan return di atas pertumbuhan return portofolio pasar, kecuali Anggrek, Bahana Dana Infrastruktur, Schroder Dana Prestasi, dan Syariah Berimbang, (3) Selama tahun 2004, hampir seluruh portofolio reksadana campuran memiliki potensi pertumbuhan return di bawah pertumbuhan return portofolio pasar, kecuali Bahana Dana Infrastruktur dan Mahanusa Dana Kapital, (4) Selama tahun 2005, hampir seluruh portofolio reksadana campuran memiliki potensi pertumbuhan return di bawah pertumbuhan return portofolio pasar, kecuali Mahanusa Dana Kapital, (5) Selama tahun 2006, hampir seluruh portofolio reksadana campuran memiliki potensi pertumbuhan return di bawah pertumbuhan return portofolio pasar, kecuali Simas Satu.

Tabel berikut ini menunjukkan potensi pertumbuhan return portofolio reksadana campuran per lima tahun dengan indikator nilai beta $(\beta)$ yang merupakan koefisien regresi dari model Jensen dan mereflekskan risiko sistematik atau risiko pasar yang dihadapi oleh portofolio:

Tabel 18

Potensi Pertumbuhan Return Setiap Portofolio Reksadana Campuran Per Lima Tahun Selama Periode 1 Januari 2002-31 Desember 2006

\begin{tabular}{clc}
\hline No & \multicolumn{1}{c}{ Reksadana } & Koefisien Regresi $(\beta)$ \\
\hline 1 & Anggrek & $0.730^{*}$ \\
2 & Bahana Dana Infrastruktur & $0.833^{*}$ \\
3 & Mahanusa Dana Kapital & $1.000^{*}$ \\
4 & Master Berimbang & $0.737^{*}$ \\
5 & Schroder Dana Terpadu & $0.815^{*}$ \\
6 & Simas Satu & $0.687^{*}$ \\
\hline
\end{tabular}

Ket. * : signifikan pada $\alpha=0.05$

Analisis dari masing-masing portofolio reksadana saham sebagaimana yang terdapat dalam tabel 18, adalah sebagai berikut : (1) Potensi pertumbuhan return reksadana Anggrek, Bahana Dana Infrastruktur, Master Berimbang, Schroder Dana Terpadu, dan Simas Satu berada di bawah pertumbuhan return pasar, (2) Potensi pertumbuhan return reksadana Mahanusa Dana Kapital cenderung sama dengan pertumbuhan return pasar.

Perbandingan Kinerja dan Potensi Pertumbuhan Return Portofolio Reksadana Saham dan Reksadana Campuran

Berdasarkan analisis terhadap kinerja dan potensi pertumbuhan return portofolio reksadana saham dan portofolio reksadana campuran, maka selanjutnya akan dilakukan analisis perbandingan. Berikut adalah tabel-tabel yang menunjukkan perbandingan antara kedua portofolio reksadana tersebut : 
Tabel 19

Analisis Kinerja Portofolio Reksadana Saham dan Portofolio Reksadana Campuran Selama Periode 1 Januari 2002 - 31 Desember 2006

\begin{tabular}{|c|c|c|c|c|c|c|c|c|c|c|c|c|c|c|c|c|c|}
\hline \multirow{3}{*}{$\begin{array}{l}\text { Portofolio } \\
\text { Reksadana }\end{array}$} & \multicolumn{15}{|c|}{ Tahun } & \multirow{3}{*}{$\frac{02-06}{S}$} & \multirow{3}{*}{$\frac{\Sigma}{S}$} \\
\hline & \multicolumn{3}{|c|}{2002} & \multicolumn{3}{|c|}{2003} & \multicolumn{3}{|c|}{2004} & \multicolumn{3}{|c|}{2005} & \multicolumn{3}{|c|}{2006} & & \\
\hline & $S$ & 1 & $\%$ & $S$ & 1 & $\%$ & $S$ & 1 & $\%$ & $S$ & 1 & $\%$ & $S$ & 1 & $\%$ & & \\
\hline Sah & 6 & 1 & 0.9 & 6 & 1 & 0.9 & 2 & 5 & 0.3 & 3 & 4 & 0.4 & 6 & 1 & 0.9 & 0.7 & 5 \\
\hline Campuran & 8 & 3 & 0.7 & 4 & 7 & 0.4 & 8 & 3 & 0.7 & 0 & 11 & 0 & 10 & 1 & 0.9 & 0.7 & 3 \\
\hline
\end{tabular}

Keterangan $: \mathrm{S}=$ Kinerja superior, $\mathrm{I}=$ Kinerja inferior

Jumlah sampel reksadana saham $=5$, dan reksadana campuran $=11$ (kecuali tahun 02-06, jumlah sampel = 6)

Tabel 20

Analisis Potensi Pertumbuhan Return Port. Reksadana Saham dan Port. Reksadana Campuran

Selama Periode 1 Januari 2002 - 31 Desember 2006

\begin{tabular}{|c|c|c|c|c|c|c|c|c|c|c|c|c|c|c|c|c|c|}
\hline \multirow{3}{*}{$\begin{array}{l}\text { Portofolio } \\
\text { Reksadana }\end{array}$} & \multicolumn{15}{|c|}{ Tahun } & \multirow{3}{*}{$\frac{02-06}{A}$} & \multirow{2}{*}{$\Sigma$} \\
\hline & \multicolumn{3}{|c|}{2002} & \multicolumn{3}{|c|}{2003} & \multicolumn{3}{|c|}{2004} & \multicolumn{3}{|c|}{2005} & \multicolumn{3}{|c|}{2006} & & \\
\hline & A & B & $\%$ & A & $B$ & $\%$ & $A$ & $B$ & $\%$ & A & $B$ & $\%$ & $\mathrm{~A}$ & $B$ & $\%$ & & $\mathrm{~A}$ \\
\hline Saham & 4 & 3 & 0.6 & 2 & 5 & 0.3 & 2 & 5 & 0.3 & 3 & 4 & 0.4 & 0 & 7 & 0 & 0.1 & 4 \\
\hline Campuran & 2 & 9 & 0.2 & 7 & 4 & 0.6 & 2 & 9 & 0.2 & 1 & 10 & 0.1 & 1 & 10 & 0.1 & 0.1 & 3 \\
\hline Keterangan & & Jur & $\begin{array}{l}\text { rtur } \\
\text { rtur }\end{array}$ & & n & $\begin{array}{l}\text { turn } \\
\text { turn }\end{array}$ & $i k$ & & $\begin{array}{l}\text { rtofo } \\
\text { port }\end{array}$ & & & $\begin{array}{l}\text { ar } \\
\text { ek }\end{array}$ & & & $n k$ & $=$ & \\
\hline
\end{tabular}

Berdasarkan tabel 19 dan 20, dapat diketahui bahwa secara umum :

1. Kinerja portofolio reksadana saham lebih tinggi daripada kinerja portofolio reksadana campuran, bila portofolio pasar (proxy: IHSG) dijadikan tolok ukur (benchmark) kinerja (dengan nilai return portofolio sebagai indikator-nya). Hal ini kemungkinan disebabkan oleh karena: (a) Pada portofolio reksadana saham, sekurangnya-kurangnya $80 \%$ dari portofolionya harus terdiri atas efek jenis saham yang memberikan tingkat return yang lebih tinggi dibandingkan jenis efek lainnya, (b) Pada portofolio reksadana campuran, persentase alokasi dana investasi pada efek jenis saham tidak ditentukan besarnya sebagaimana halnya pada portofolio reksadana saham, sehingga walaupun ada kemungkinan saham merupakan jenis efek yang menyerap dana investasi lebih besar, tetapi persentase-nya relatif lebih rendah dibandingkan dengan portofolio reksadana saham sendiri.

2. Potensi pertumbuhan return portofolio reksadana saham lebih tinggi daripada potensi pertumbuhan return portofolio reksadana campuran. Hal ini berkaitan dengan penjelasan dalam butir (a), bahwa saham merupakan jenis efek yang menyerap dana alokasi yang cukup besar pada kedua jenis portofolio 
reksadana, namun dengan beberapa kemungkinan: (a) Pada portofolio reksadana saham, selain berinvestasi pada saham-saham unggulan (seperti LQ 45 yang relatif mahal namun memiliki nilai beta yang rendah), komposisi portofolio juga terdiri dari saham-saham bukan unggulan (harga relatif murah namun memiliki nilai beta yang tinggi), (b) Pada portofolio reksadana campuran, komposisi sahamnya sebagian besar terdiri dari saham-saham unggulan.

\section{SIMPULAN}

Berdasarkan pembahasan yang telah dilakukan, maka dapat dibuat beberapa kesimpulan, sebagai berikut :

1. Kinerja portofolio reksadana saham dan portofolio reksadana campuran (yang didasarkan pada tingkat return), secara keseluruhan lebih rendah dibandingkan dengan kinerja portofolio pasar.

2. Potensi pertumbuhan return portofolio reksadana saham dan portofolio reksadana campuran, secara keseluruhan lebih rendah dibandingkan dengan potensi pertumbuhan return portofolio pasar.

3. Kinerja dan potensi pertumbuhan return portofolio reksadana saham, secara keseluruhan lebih tinggi daripada kinerja dan potensi pertumbuhan return portofolio reksadana campuran.

Untuk penelitian selanjutnya yang terkait dengan keterbatasan dalam penelitian ini :

a. Perlunya penggunaan periode pengamatan yang lebih panjang dengan melibatkan sub periode pengamatan yang lebih banyak. Hal ini perlu dilakukan untuk mengetahui bagaimana kinerja dan potensi pertumbuhan return portofolio reksadana dalam jangka waktu yang lebih panjang.

b. Perlunya melakukan observasi ke perusahaan investasi, untuk mengetahui secara langsung bagaimana proses pengambilan keputusan investasi yang dilakukan oleh manajer investasi sehingga analisis dapat dilakukan secara lebih mendalam dan objektif.

c. Perlunya mencoba model lain yang lebih akurat dan objektif dalam menganalisis kinerja dan potensi pertumbuhan return portofolio reksadana.

\section{Daftar Referensi}

Cahyono, Jaka E., 2002, Cara Jitu Meraih Untung dari Reksadana, PT. Elex Media Komputindo, Jakarta

Chuan, Tan Hoon, 1995, The Investment Performance of Unit Trust Funds in Malaysia, Capital Market Review, Vol. 3 No. 2 
Dennis, Manurung dan Nachrowi, 2004, Analisis Determinasi Kinerja Reksadana Pendapatan Tetap di Indonesia Periode 1992 - 2003 (Penggunaan Model Jensen dan Model Gudikunst), Jurnal Riset Akuntansi Indonesia, Jakarta

Elton, Edwin J. and M.J. Gruber, 2003, Modern Portfolio Theory and Investment Analysis, Sixth Edition, John Wiley \& Sons, New York

Jogiyanto, 1998, Teori Portofolio dan Analisis Investasi, Edisi Pertama, PT. BPFE, Yogyakarta

Jones, 2000, Investments : Analysis and Management, Seventh Edition, John Wiley \& Sons, New York

Kuncoro, Mudrajat, 2001, Metode Kuantitatif-Teori dan Aplikasi untuk Bisnis dan Ekonomi, UPP AMP YKPN, Yogyakarta

Lantara, I Wayan Nuka, 2000, Analisis Stabilitas dan Prediktabilitas Beta Saham : Studi Empiris di BEJ, Universitas Gadjah Mada, Yogyakarta

Mohamed and Nassir, 1995, The Performance of Unit Trusts in Malaysia: Some Evidence, Capital Market Review, Vol. 3 No. 2

Reily and Brown, 2003, Investment Analysis and Portfolio Management, Seventh Edition, South-Western USA

Scott and Brown, 1980, Biased Estimators and Unstable Betas, The Journal of Finance, Vol. XXXV No. 1

Sembiring, Ferikawita M., 2005, Evaluasi Kinerja serta Analisis Stabilitas dan Prediktabilitas Faktor Risiko Sistematik pada Reksadana Saham, Tesis, Universitas Padjadjaran, Bandung

Tandelilin, Eduardus, 2001, Analisis Investasi dan Manajemen Portofolio, Edisi Pertama, PT. BPFE, Yogyakarta

Utomo, Eko Priyo dan Nugraha, Ubaidillah, 2002, Reksadana : Solusi Perencanaan Investasi di Era Modern, PT. SUN, Jakarta

Yuliati, Prasetyo dan Tjiptono, 1996, Manajemen Portofolio dan Analisis Investasi, Penerbit ANDI, Yogyakarta

Sumber-sumber lain:

Panduan Reksa Dana, BAPEPAM, 1997

Website BAPEPAM : www. Bapepam.go.id

\footnotetext{
* Ferikawita Magdalena Sembiring dan Titianingsih Madjan adalah dosen tetap di Fakultas Ekonomi Universitas Jenderal Achmad Yani (UNJANI). Kritik dan saran dapat langsung menghubungi penulis dengan alamat email ferikawita@yahoo.com dan titianingsih@yahoo.com
} 